\title{
Triatomines: Trypanosomatids, Bacteria, and Viruses Potential Vectors?
}

\author{
Caroline Barreto Vieira ${ }^{1}$, Yanna Reis Praça ${ }^{1}$, Kaio Luís da Silva Bentes ${ }^{2}$, \\ Paula Beatriz Santiago ${ }^{2}$, Sofia Marcelino Martins Silva ${ }^{2}$, Gabriel dos Santos Silva ${ }^{2}$, \\ Flávia Nader Motta ${ }^{2,3}$, Izabela Marques Dourado Bastos ${ }^{2}$, Jaime Martins de Santana ${ }^{2}$ and \\ Carla Nunes de Araújo ${ }^{2,3 *}$ \\ 'Programa de Pós-Graduação em Ciências Médicas, Faculdade de Medicina, Universidade de Brasilia, Brasilia, Brazil, \\ ${ }^{2}$ Laboratório de Interação Patógeno-Hospedeiro, Instituto de Ciências Biológicas, Departamento de Biologia Celular, \\ Universidade de Brasilia, Brasília, Brazil, ${ }^{3}$ Faculdade de Ceilândia, Universidade de Brasília, Brasilia, Brazil
}

\section{OPEN ACCESS}

Edited by:

Brice Rotureau, Institut Pasteur, France

Reviewed by:

Mariane B. Melo, Massachusetts Institute of

Technology, United States

Oscar Daniel Salomón, National Institute of Tropical Medicine

(INMeT), Argentina

*Correspondence:

Carla Nunes de Araújo cnunes@unb.br

Specialty section:

This article was submitted to

Parasite and Host

a section of the journal

Frontiers in Cellular and Infection

Microbiology

Received: 09 August 2018

Accepted: 29 October 2018

Published: 16 November 2018

Citation:

Vieira $C B$, Praça YR, Bentes $K L S$, Santiago PB, Silva SMM, Silva GS, Motta FN, Bastos IMD, Santana JM and Araújo CN (2018) Triatomines:

Trypanosomatids, Bacteria, and Viruses Potential Vectors?

Front. Cell. Infect. Microbiol. 8:405.

doi: 10.3389/fcimb.2018.00405
Triatominae bugs are the vectors of Chagas disease, a major concern to public health especially in Latin America, where vector-borne Chagas disease has undergone resurgence due mainly to diminished triatomine control in many endemic municipalities. Although the majority of Triatominae species occurs in the Americas, species belonging to the genus Linshcosteus occur in India, and species belonging to the Triatoma rubrofasciata complex have been also identified in Africa, the Middle East, South-East Asia, and in the Western Pacific. Not all of Triatominae species have been found to be infected with Trypanosoma cruzi, but the possibility of establishing vector transmission to areas where Chagas disease was previously non-endemic has increased with global population mobility. Additionally, the worldwide distribution of triatomines is concerning, as they are able to enter in contact and harbor other pathogens, leading us to wonder if they would have competence and capacity to transmit them to humans during the bite or after successful blood feeding, spreading other infectious diseases. In this review, we searched the literature for infectious agents transmitted to humans by Triatominae. There are reports suggesting that triatomines may be competent vectors for pathogens such as Serratia marcescens, Bartonella, and Mycobacterium leprae, and that triatomine infection with other microrganisms may interfere with triatomine-T. cruzi interactions, altering their competence and possibly their capacity to transmit Chagas disease.

Keywords: kissing bugs, vector competence, infectious diseases, Chagas disease, pathogens

\section{INTRODUCTION}

Vector-borne diseases (VBDs) are human illnesses caused by parasites, viruses, and bacteria that are usually transmitted by a bloodsucking arthropod. According to the World Health Organization (WHO) VBDs together account for around 17\% of all infectious diseases in the world, which are mainly distributed in tropical and subtropical areas, affecting poorest populations. However, environmental changes and globalization have placed many more people living in other parts of the world at risk of contracting VBDs. The emergence/re-emergence of these diseases is burdening the health systems in many countries due to possible epidemic outbreaks and their impact in morbidity and mortality (WHO, 2017). 
Triatominae insects (Hemiptera: Reduviidae) (Lent and Wygodzinsky, 1979; Jurberg et al., 2014) are a diverse subfamily of ectoparasites mainly distributed across Americas (Guarneri et al., 2000; Otálora-Luna et al., 2015) (Figure 1). Six species belonging to the genus Linshcosteus occur in India, and species belonging to Triatoma have been also identified in Africa, the Middle East, South-East Asia and in the Western Pacific (Figure 1, Table S1). Currently, the 151 Triatominae species described are grouped in 17 genera and organized into 5 tribes: Aberproseniini, Bolboderini, Cavernicolini, Rhodiniini, and Triatomini (Table S1) (Alevi et al., 2014, 2016; Souza et al., 2016; da Rosa et al., 2017). They are typically found in a wide range of sylvatic environments frequently associated to several wild vertebrate hosts, possibly in their nests and burrows. Contact with humans occurs when men enter in forested areas or when they reach urban areas by flying and colonize human dwellings (Lazzari et al., 2013).

All species are considered able to transmit Trypanosoma cruzi, agent of Chagas disease. However those belonging to the genera Triatoma, Rhodnius and Panstrongylus have greatest epidemiological importance in Latin America (Cavassin et al., 2014), as they have adapted to colonize peridomestic and domestic environments, coming into close contact with domestic animals and humans. Domiciliation occurs through the loss of habitat due to irregular environment exploitation, such as deforestation and burnings (Dias and Schofield, 1998; Almeida et al., 2009) or through the loss of primary hosts, which can triggers a switch to accessible humans (Schofield, 1988).

T. cruzi and other pathogens infection within Triatominae colonies is due mainly to the vector blood feeding behavior. They are obligate hematophagous insects, exhibiting behavioral, morphological and molecular adaptations to feed on a variety of vertebrate blood throughout their life cycle (Lazzari et al., 2013), in which they undergo five nymphal stages before reaching adulthood (Jurberg et al., 2014). Therefore, their dietary behavior ensures the scenario to act as potential vectors of multiple pathogens to humans at any developmental stage. Moreover, exposure to triatomine bites and feces can result in immunological reactions (Walter et al., 2012), such as swelling, severe fever, itching at the bite site, and anaphylaxis (Klotz et al., 2010; Dujardin et al., 2015).

Thus, from the close relationship of Triatominae with vertebrate hosts, beyond T. cruzi, different triads of interaction (vector/pathogen/vertebrate host) may arise, allowing new infection routes for other microorganisms, such as bacteria and viruses, in cases Triatominae species show vector competence and vectorial capacity. Vectorial capacity is the ability of a vector to transmit a pathogen in a given locality at a definite time. It comprises the vector interactions with the infectious agent and with the vertebrate host(s), and is affected, for instance, by vector density, longevity, host preference, feeding behavior, and vector competence. Precisely, vector competence embodies vectorpathogen interactions, encompassing specifically the ability of a vector to become infected by and transmit a pathogen. It includes susceptibility to infection, permissiveness for pathogen reproduction and development, transmission efficiency and duration of extrinsic incubation period, which is the time from the uptake of an infectious meal to the time it is capable of transmitting the pathogen (Higgs and Beaty, 2004).

To be a competent vector, triatomine has to acquire the pathogenic microorganism from an infected host, to allow its replication in the midgut or to spread to the hemocoel in order to enter into the salivary glands. Hence, pathogens may be carried from the bug to the human host during insect bite by two different routes: via contaminated saliva released into host blood vessel or via contact with contaminated feces deposited at the host skin or near mucosa. It is worth mentioning that oral infection may also occur in case of food contamination with triatomine feces/saliva. An additional route of pathogen transmission may be xenodiagnosis, a diagnostic method that uses Triatominae nymphs as a biological culture medium for the detection of T. cruzi infection. Pathogens have been developing adaptations to exploit vector biology, behavior and ecology, and mainly, different mechanisms of transfer from one host to another to continue its species maintenance. Understanding all possible spreading routes of pathogens is crucial to prevent infectious diseases. Thus, considering the diversity of pathogens that Triatominae may acquire during blood feeding, the aim of this review was to examine published literature and summarize current information of triatomine competence to transmit, beyond T. cruzi, other pathogens to humans.

\section{MICROORGANISMS TRANSMITTED THROUGH TRIATOMINE/MAN CONTACT AND THEIR POSSIBLE ROLE IN HUMAN HEALTH}

\section{Trypanosomatids}

\section{Trypanosoma cruzi and Chagas Disease}

The Trypanosomatidae family encompasses various obligate parasites, including the protozoa T. cruzi that causes Chagas disease (Hoare, 1972; Cavalier-Smith, 2016). The transmission of Chagas disease by Triatominae is very well reported in literature. Infection with vector-borne $T$. cruzi begins when metacyclic trypomastigotes, which are motile forms of the parasite, penetrate into the vertebrate host through the triatomine feces and urine. Once in the vertebrate host, these forms, which have evolved to survive inside host cells, infect nucleated cells. Within the cell, they differentiate into amastigotes in a phagosomal compartment known as the parasitophorous vacuole, escape to the cytoplasm and replicate asexually through longitudinal binary division to form several amastigotes. As the cell becomes full of amastigotes, these convert into trypomastigotes and breach it, invading adjacent tissues and spreading to distant sites through bloodstream and lymphatics. The parasite population expands due to repeated cycles of cell invasion and replication, which lead to immune responses and can give rise to Chagas-associated pathologies (Tyler and Engman, 2001).

When triatomines take a blood meal, bloodstream trypomastigotes enter the midgut and differentiate into epimastigotes, amastigotes, and spheromastigotes (Rassi et al., 2010; Teixeira et al., 2011). Epimastigotes divide through 


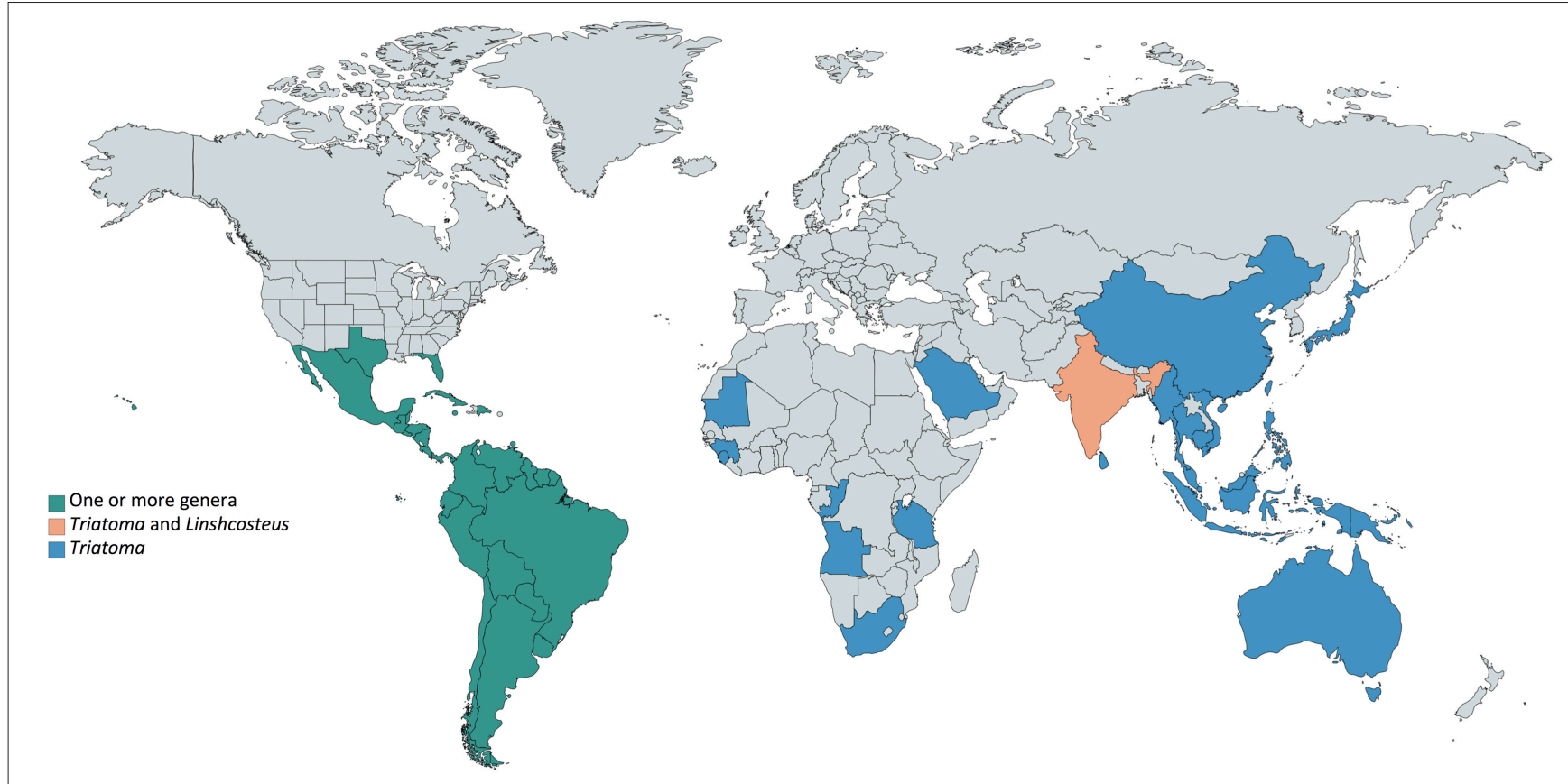

FIGURE 1 | Worldwide Triatominae distribution. Triatominae species are present mainly in Americas (green), in which countries one or more genera can be found. Outside the American continent (blue), the only genus reported is Triatoma, except in India (soft orange), where Triatoma and Linshcosteus are reported.

longitudinal binary asexual reproduction repeatedly, which then migrate to the rectum, where they differentiate into infective and non-replicative metacyclic trypomastigotes, process called metacyclogenesis (Figure 2). T. cruzi infection intensity is triatomine species specific (Kollien and Schaub, 2000), as the conditions for its development in the gut vary substantially (Garcia et al., 2010). Therefore, the protozoan is capable of causing significant physiological changes such as delay in the development of Triatoma infestans nymphs (Schaub, 1989), decline in Rhodnius prolixus adult life span (Schaub, 1989) and of blood meal ingestion in infected Triatoma dimidiata nymphs (Schaub et al., 2011). Although epimastigotes and metacyclic trypomastigotes are eliminated along with the insect feces, only the latter are able to infect vertebrates (Schuster and Schaub, 2000), reach the vertebrate bloodstream through preexistent lesions or bite resultant breaches of the skin, or through mucosal tissues, repeating the life cycle (Billingsley and Downe, 1986; Figueiredo et al., 2000; Garcia et al., 2007). A balance among T. cruzi strain, inoculated burden, the innate and acquired immunological responses seems to be critical for the parasite control in the vertebrate host (Tarleton, 2007; Gil-Jaramillo et al., 2016).

Endemic to the continental part of Latin America, Chagas disease (American trypanosomiasis) affects approximately 8 million people worldwide (WHO, 2018a). It has been increasingly detected in non-endemic countries like USA, Canada, and countries in Europe and Western Pacific Region, due primarily to people movement between Latin America and the rest of the world, being an emerging infectious disease in these regions (WHO, 2018b). It is interesting to note that in the southern of USA recent surveillance data unveil Triatominae adults and nymphs in domestic and peridomestic areas, increasing human T. cruzi infection by vector-borne route, becoming Chagas disease a public health concern in this country (Montgomery et al., 2014; Edwards et al., 2017; Curtis-Robles et al., 2018).

In Vietnam, in the southeastern Asia, Triatoma rubrofasciata has been reported in high densities associated with rats and chickens close to human dwellings in rural and, specially, in urban areas. In the latter, T. rubrofasciata adults were reported hiding in people beds and feeding on them while sleeping, in buildings from the ground to the eighth floor. Although it is known this species transmit T. cruzi in Latin America and Trypanosoma conorhini worldwide, these trypanosomatids have not been detected in blood smears from individuals bitten by this bug. Closely related to T. rubrofasciata complex, Linshcosteus is uniquely distributed in Indian. Due to human migration and triatominae anthropophilia, T. cruzi infection emergence in Asia and India can arise (Dujardin et al., 2015).

Chagas disease warrants attention as it is considered the parasitic disease with the major socioeconomic impact in Latin America, being responsible for loss of productivity with an estimated value of US\$ 1.2 billion annually (WHO/TDR, 2012).

\section{Trypanosoma rangeli}

Another parasite from the Trypanosomatidae family infecting humans and other vertebrates is T. rangeli (D'Alessandro, 1976; Guhl and Vallejo, 2003). Five phylogenetic lineages named TrA, $\operatorname{TrB}, \operatorname{TrC}, \operatorname{Tr} \mathrm{D}$, and $\operatorname{TrE}$ have been identified to date, $\operatorname{TrB}$ being the most phylogenetically divergent one (Da Silva et al., 2004, 


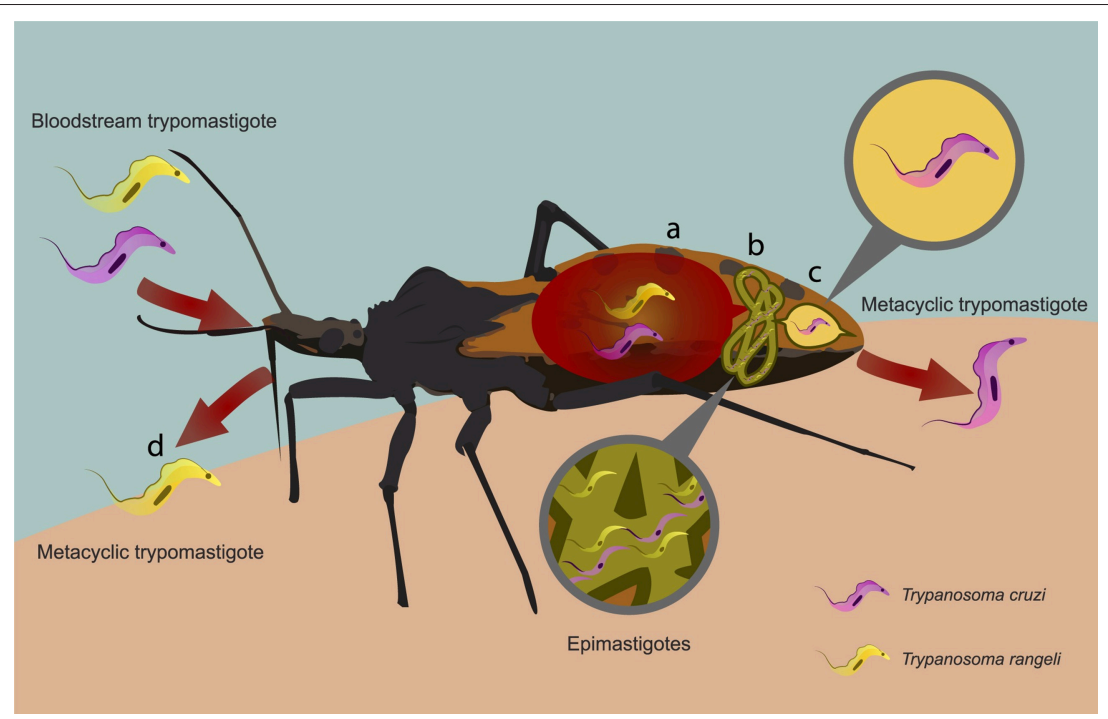

FIGURE 2 | Schematic representation of Trypanosoma cruzi and Trypanosoma rangeli life cycles in the Triatominae. Triatomine infection occurs due to the ingestion of bloodstream trypomastigotes during the blood meal acquisition from a vertebrate host. (A) After ingestion, they transform into epimastigotes in the insect midgut. (B) T. cruzi epimastigotes multiply and then (C) migrate to the rectum where they differentiate into infective and non-replicative metacyclic trypomastigotes. These forms are eliminated with the triatomine feces and urine after a successful blood feeding. (B) T. rangeli epimastigotes reach the hemolymph and multiply, and then invade the salivary glands, differentiate into metacyclic trypomastigotes, (D) which are injected with saliva during the feeding process.

2009; Maia da Silva et al., 2004; Maia Da Silva et al., 2007; Ortiz et al., 2009; Caballero et al., 2015). TrA, TrB, and TrC lineages were reported to infect humans (Da Silva et al., 2004, 2009; Maia Da Silva et al., 2007; Ortiz et al., 2009; Pinto et al., 2012, 2015; Sincero et al., 2015; Dario et al., 2016, 2017). T. rangeli differs in life cycle, host infection and immune evasion both in triatomine and vertebrate hosts in comparison with T. cruzi (Espinosa-Álvarez et al., 2018).

Vector-borne T. rangeli transmission begins when metacyclic trypomastigotes penetrate into the vertebrate host through the triatomine saliva. Paim et al. (2013) showed that a 5th nymph of a T. rangeli-infected $R$. prolixus could carry up to 100,000 metacyclic trypomastigotes in its salivary glands. Approximately half of them can be released during blood feeding into the bite site (Ferreira Lde et al., 2015). Once in the vertebrate hosts, these forms may develop a multiplicative cycle. There is no strong evidence of reproductive forms of $T$. rangeli in these hosts, although some studies suggest their presence in vertebrates (de Scorza et al., 1986; Urdaneta-Morales and Tejero, 1986; Osorio et al., 1995; Ferreira Lde et al., 2015). Moreover, Ferreira et al. suggest that $T$. rangeli can hide in some tissues or organs, as it was rarely found circulating in mouse blood, even after an infected triatomine had injected a huge number of parasites (Ferreira Lde et al., 2015).

T. rangeli (sub-genera Tejeraia), as well as Trypanosoma brucei and Trypansoma evansi (sub-genera Trypanozoon), is classified as a Salivarian trypanosome because it multiplies in the anterior part of the vector digestive tract (Desquesnes et al., 2007). So, when triatomines feed on $T$. rangeli-infected hosts, trypomastigotes get into the midgut and differentiate into epimastigotes. These forms cross the gut epithelium, replicate in the hemolymph and then reach the salivary glands where they differentiate into metacyclic trypomastigotes. The cycle reinitiates when these forms are transmitted to mammals during the next triatomine bite (D’Alessandro, 1976) (Figure 2). T. rangeli is transmitted specially by Triatominae of the Rhodniini tribe. Its metacyclic trypomastigotes were already reported in Rhodnius domesticus, Rhodnius nasutus, Rhodnius neglectus, Rhodnius pallescens, R. prolixus, Rhodnius robustus, Rhodnius brethesi, Rhodnius colombiensis, Rhodnius ecuadoriensis, Rhodnius dalessandroi, Rhodnius pictipes, and Rhodnius neivai salivary glands (Guhl and Vallejo, 2003; Vallejo et al., 2009, 2015; Castro et al., 2017). Nevertheless, it was also reported in Triatoma carrion, Panstrongylus chinai and Panstrongylus rufotuberculatus species from the Triatominii tribe (Ocaña-Mayorga et al., 2015).

T. rangeli is capable of causing reduction in $R$. prolixus fecundity and fertility (Fellet et al., 2014), reduction in negative phototaxis and in $R$. prolixus expression of cGMP-dependent protein kinase gene, an ortholog of Drosophila melanogaster foraging gene reported to control the locomotion activity (Marliére et al., 2015), increase in mortality, defective, delayed or absent molts and tissue damages (Ferreira et al., 2010), among other effects in the infected triatomines (Guhl and Vallejo, 2003; Peterson and Graham, 2016). However, it seems R. prolixus coinfection with $T$. rangeli and T. cruzi ameliorate adverse effects of distinct infections, helping the insect to tolerate greater parasite infections (Peterson et al., 2016).

T. rangeli occurs from Central to South America (Grisard et al., 1999b). Although it is not considered a human pathogen, this trypanosomatid deserves attention as it shares biological characteristics, antigens, geographical distribution, insect and vertebrate hosts with T. cruzi. Mixed infections with T. cruzi 
are observed in humans, sylvatic and domestic mammals (Grisard et al., 1999b; Guhl and Vallejo, 2003). Thus, T. rangeli transmission by $T$. cruzi vectors is biologically and epidemiologically important due to crossed serological reactions (Guhl and Marinkelle, 1982; Guhl et al., 1987; Coura et al., 1996; Cuba Cuba, 1998; Calzada et al., 2010), what may result first in increased diagnostic test costs, and second in harms to human health due to Chagas disease drug toxicity where false positives are not detected (Grisard et al., 1999a). To circumvent this possibility, Moraes et al. evaluated the serological cross-reactivity between epimastigotes and trypomastigotes from T. cruzi and T. rangeli using sera of acute and chronic chagasic patients by indirect immunofluorescence and immunoblotting assays. These authors recommend retesting, in areas where there is overlapped distribution of both species, Chagas disease positive sera with $T$. rangeli trypomastigote antigens to avoid misdiagnosis (de Moraes et al., 2008).

\section{Bacteria \\ Serratia marcescens}

Serratia genus (Enterobacteriaceae family) contains 14 species and 2 subspecies (Mahlen, 2011). They have been associated with human infections and reported as a symbiont in the microbiota of hematophagous insects (Grimont and Grimont, 1978; Grimont et al., 1979; Azambuja et al., 2004). In humans, S. marcescens is an important opportunistic gram-negative bacteria reported to cause wound, urinary tract, bloodstream and ocular infections, pneumonia and other respiratory diseases, meningitis, endocarditis, among other clinical diseases (Mahlen, 2011; González-Juarbe et al., 2015). The clinical and epidemiological significance are associated with sporadic hospital infection outbreaks due to $S$. marcescens strains ability to produce $\beta$ lactamases, which confer resistance to $\beta$-lactams and antiseptic agents available (Maragakis et al., 2008; Carvalho et al., 2010). Many outbreaks are frequently reported worldwide especially in neonatal intensive care units, where the bacteria usually spread rapidly and is associated with significant morbidity and mortality. The sources of the outbreaks have been associated to contaminated laryngoscope blades, hands, ventilator equipment, disinfectants, and breast pumps (Gransden et al., 1986; Jones et al., 2000; Sartor et al., 2000; Jang et al., 2001; Villari et al., 2001; Fleisch et al., 2002; Uduman et al., 2002; Cullen et al., 2005; Montagnani et al., 2015; Åttman et al., 2018).

Azambuja et al., isolated $S$. marcescens biotype Ala from the midgut of labroratory-reared $R$. prolixus (Azambuja et al., 2004), confirming previous reports on the occurrence of this species in triatomine gut (Figueiredo, 1995). Following feeding, this gramnegative bacillus rapidly multiplied and showed hemolytic and trypanolytic effects, the latter on T. cruzi Y strain but not on T. cruzi DM28c clone. Many strains of S. marcescens produce a reddish pigment named prodigiosin that is an important compound for the action against the parasite in the insect midgut (Azambuja et al., 2004). This report provides evidence that $R$. prolixus may be a competent vector for $S$. marcescens, as it was able to maintain infection in the gut, and that bacteria may be eliminated within the feces. Also suggests that $S$. marcescens may compete with T. cruzi, reducing $R$. prolixus competence for this trypanosomatid. On the other hand, S. marcescens biotype Ala did not raise triatomine mortality (Azambuja et al., 2004). The conduction of transmission studies from triatomines to mice would help to confirm the potential of $R$. prolixus to serve as vector for $S$. marcescens.

To date $S$. marcescens vector-borne transmission was not reported, but it is important to emphasize this possible mode of transmission. It is possible $S$. marcescens living in triatomine midgut to be acquired during the consumption of food containing the contaminated feces of an infected triatomine or maybe vector-borne through contaminated feces contact with open wounds or mucous membranes of a susceptible host. Future studies may evidence this possibility and indicate the consequences for human health.

\section{Bartonella}

Bartonella genus belongs to the Bartonellaceae family of the alphaproteobacteria (Regier et al., 2016), along with Rickettsia and Brucella (Sanchez Clemente et al., 2012) and contains 36 species, characterized by coccobacillary or bacillary rods. These pleomorphic fastidious gram-negative bacteria are considered a facultative intracellular pathogen (Maguiña and Gotuzzo, 2000). Human body lice, sandflies, cat fleas, flies and ticks are Bartonella vectors to humans and other mammals (Tsai et al., 2011). The vector-borne is the most relevant route of transmission (Pons et al., 2016).

A novel Bartonella genotype, named Candidatus Bartonella rondoniensis, closely related to Bartonella bacilliformis and Bartonella ancashensis, severe human pathogens, was described in the sylvatic triatomine Eratyrus mucronatus (Laroche et al., 2017). This new genotype is also related to B. bovis that has been observed to cause endocarditis in cats, which are accidental hosts of this species (Maillard et al., 2007). E. mucronatus feeds on bats and other small mammals (Castro et al., 2010), which are sources of virus and bacteria (Mühldorfer, 2013), including Bartonella (Laroche et al., 2017). Although sylvatic, this triatomine is attracted to artificial light sources (Castro et al., 2010) and has been reported in the proximity and inside houses. By now, Laroche et al. suggest that this species may host pathogenic bacteria (Laroche et al., 2017). An experimental model of infection would help to confirm if E. mucronatus is a competent vector for Bartonella species and act as their vector to humans. One possibility is that in these arthropods, Bartonella migrates to, replicate in the salivary glands and is transmitted during the bite.

In humans, $B$. bacilliformis is transmitted through the bite of infected Lutzomyia verrucarum, Lutzomyia peruensis, among other phlebotomine sandflies. This disease, named Carrion's disease, is endemic in South America and was the first human bartonellosis described. Carrion's disease can occur in two distinct concomitant or independent syndromes. The first is known as Oroya fever, which is characterized by hemolytic fever and bacteremia that without treatment can cause $40-88 \%$ death. Verruga peruana is the second syndrome, characterized by hemangiomas owed to endothelium infection (Minnick et al., 2014). B. bacilliformis closely related B. ancashensis was isolated from patients' blood with chronic verruga peruana, being 
suggested as a second agent of the disease (Mullins et al., 2015). Other Bartonella species may cause endocarditis, B. quintana causes trench fever and $B$. henselae causes cat scratch disease (Regier et al., 2016).

\section{Mycobacterium leprae}

$M$. leprae belongs to Mycobacteriaceae family and causes leprosy, a disfiguring chronic systemic infectious disease. Early diagnosis and the available treatment with multi-drug therapy significantly reduced the disease burden in recent decades. However, the lack of awareness about early signs of leprosy that contributes to a delay in diagnosis, and the persistent stigma and discrimination against affected people are factors that complicate the fight against leprosy. The global incidence of new cases was approximately 213,000 in 2014, and the highest prevalence rates are observed in Brazil, India and Indonesia, which together account for $81 \%$ of the newly diagnosed cases globally (WHO, 2016). To date, the exact mechanism of leprosy transmission is not completely understood, but it is supposed that transmission occurs due to the inhalation of infectious aerosols released by untreated cases of the disease or by direct contact from an infected person to a susceptible individual (Scollard et al., 2006; WHO, 2015). Interestingly, studies point out the viability of $M$. leprae outside human body and its existence in the environment, suggesting a different possibility in disease transmission (Desikan and Sreevatsa, 1995; Matsuoka et al., 1999; Turankar et al., 2012, 2016).

Recently, a report from Triatominae gut microbiomes revealed the presence of Mycobacterium in Triatoma protracta species microbiome profile (Rodríguez-Ruano et al., 2018). A further study evaluated the potential of $M$. leprae transmission by some insects and it was shown that $R$. prolixus might be able to transmit these bacteria, once they were present in $R$. prolixus feces (Neumann Ada et al., 2016). Perhaps the approximately $50 \%$ of Triatominae species found in Brazil, Linshcosteus (6 species) in India and T. rubrofasciata in Indonesia (Table S1) could help leprosy transmission in these three countries with the highest global incidences of the disease. McFadzean and Macdonald evaluated the possible role of mosquitoes and bed bugs in leprosy transmission by allowing infected and control insects to take a blood meal on volunteers and found no difference in transmission (McFadzean and Macdonald, 1961). Almost two decades later, the presence of $M$. leprae was reported in the proboscis, cuticle and blood smears from mosquitoes and ticks (de Souza-Araujo, 1942; Banerjee et al., 1991), suggesting arthropods could act as biological or mechanical vectors to these bacilli (Kirchheimer, 1976; Benchimol and Romero Sa, 2003).

Armadillos (Dasypus novemcinctus), which are parasitized by triatomines (Lainson et al., 1979), are a natural reservoir for $M$. leprae (Walsh et al., 1975; Smith et al., 1983) and also for T. cruzi (Lainson et al., 1979; Paige et al., 2002). Moreover, it is important to highlight that a study reported wild armadillos as well as patients with leprosy infected with the same strain of M. leprae (Truman et al., 2011). In this context, it is a topic of concern the overlapping geographic distribution of Triatominae species and the endemicity of leprosy in some regions, as triatomines that are transitioning from wild environments to the domiciliary ones may be a potential source of $M$. leprae transmission to humans (Neumann Ada et al., 2016), supporting that old hypothesis that leprosy can be vector-borne transmitted through the insect feces containing the bacteria when in contact with host wound or mucosa (Kirchheimer, 1976; Benchimol and Romero Sa, 2003; Neumann Ada et al., 2016).

\section{Virus}

\section{Human Immunodeficiency Virus (HIV) and Hepatitis B Virus (HBV)}

HIV (genus Lentivirus, Retroviridae family) is own singlestranded RNA virus that infects human $\mathrm{CD} 4^{+} \mathrm{T}$ lymphocytes and macrophages. HIV genome contains nine ORFs that encode for 15 proteins (Frankel and Young, 1998), fundamental to replication and evasion from host defense. HIV causes infection in approximately 36.7 million people worldwide and was responsible for 1.0 million HIV-related causes deaths in 2016 (WHO, 2018c).

HBV (Hepadnaviridae family) infection causes acute and chronic hepatitis, and in severe forms, can lead to the development of cirrhosis and hepatocellular carcinoma (Liang, 2009). HBV causes infection in approximately 257 million people and was responsible for 887,000 deaths in 2015 (WHO, 2018d).

HIV- or HBV-infected patients were submitted to xenodiagnosis to investigate HIV or HBV possible transmission by triatomines (Granato et al., 1987; Nuzzo et al., 1998). For triatomines fed on AIDS patients in whose blood p24 HIV antigen was detected, no antigen was detected in the feces samples analyzed $24 \mathrm{~h}$ or $48 \mathrm{~h}$ post-blood meal (Nuzzo et al., 1998). For HBV, samples of feces and hemolymph were analyzed periodically and revealed that the hepatitis B surface antigen ( $\mathrm{HBsAg}$ ) was eliminated until 15 days post-blood meal. These authors concluded that although the HBV transit by the triatomine gastrointestinal tract, these insects may not yield efficient HBV infection (Granato et al., 1987).

In a previous study, human blood samples obtained from wild caught Panstrongylus, Rhodnius, and Triatoma were evaluated for the presence of HBsAg by haemagglutination and radioimmunoassay techniques. By the former, seven samples were presumably positive for $\mathrm{HBsAg}$, but by the latter, only one, obtained from a Triatoma sordida specimen, was positive for the antigen (Candeias et al., 1976). These studies did not reveal a trend in viruses' transmission by triatomines, but instead highlight that efforts should be made to ensure greater consistence among studies that evaluate this task.

\section{Triatoma Virus}

Non-enveloped Triatoma virus ( $\mathrm{TrV}$ ) was first identified in T. infestans species in Argentina (Muscio et al., 1987). $\mathrm{TrV}$ belongs to the genus Triatovirus (Agirre et al., 2011) of the Dicistroviridae family (Czibener et al., 2000), in which viruses own positive-sense single-stranded RNA. Its genome contains two open reading frames, separated by an intergenic region, coding structural, and non-structural polyproteins (Johnson and Christian, 1998; Sasaki et al., 1998; 


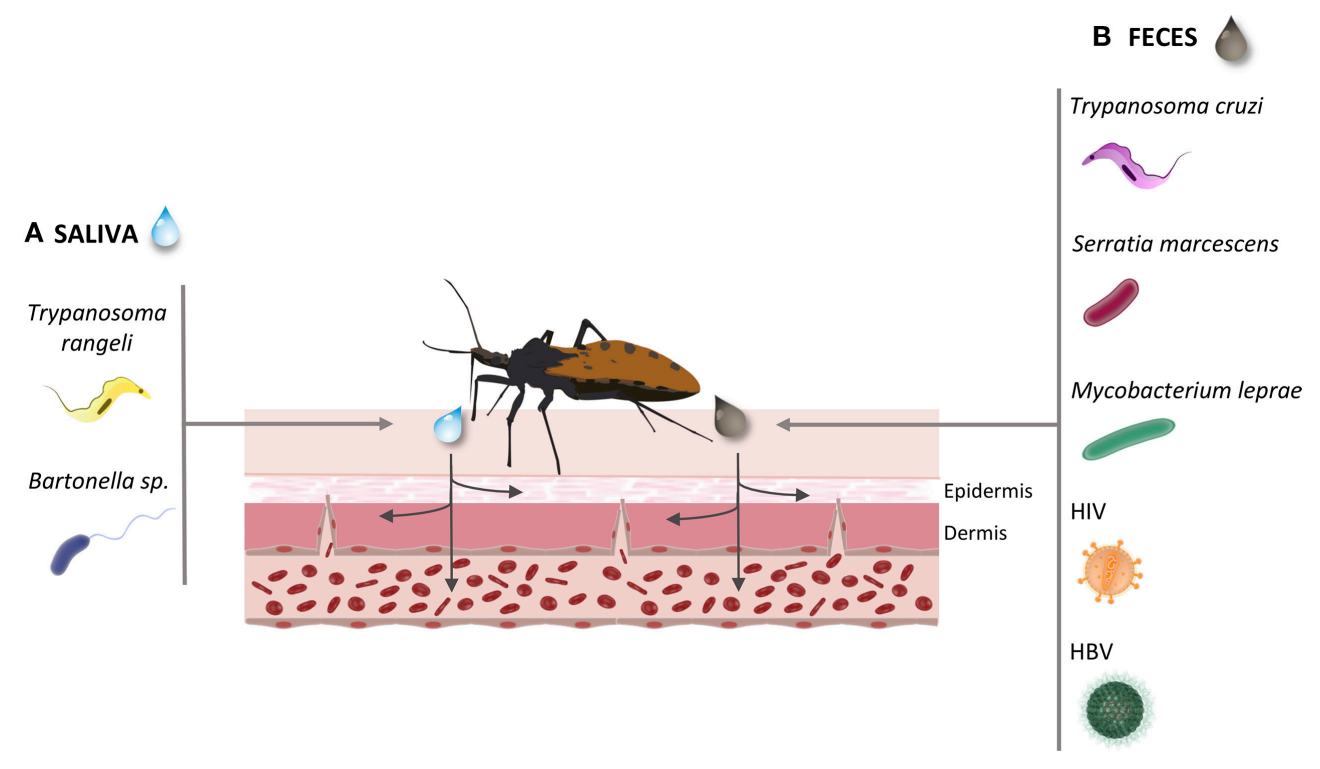

FIGURE 3 | Common infection routes of the pathogens transmitted by Triatominae. During the Triatominae bite, the infected vector may transmit different pathogens to the host's vascular endothelium. (A) Via saliva inoculation: Trypanosoma rangeli; Bartonella sp. (B) Via feces penetration in mucous or open wound: Trypanosoma cruzi; Serratia marcescens; Mycobacterium leprae; Human immunodeficiency virus; Hepatitis B virus.

Czibener et al., 2000; Domier et al., 2000; Wilson et al., 2000).

So far, $\operatorname{TrV}$ is the only pathogenic virus described in Triatominae. TrV transmission among triatomines occurs vertically, through cannibalism or fecal-oral route (Muscio et al., $1987,1988,2000)$. It replicates in the intestinal epithelium cells of triatomines, causing leg paralyzes, delayed development, reduced fertility and death (Muscio et al., 1987, 1988; Rozas-Dennis and Cazzaniga, 2000).

$\operatorname{TrV}$ average prevalence in $T$. infestans is greater than of $T$. cruzi (Marti et al., 2009) and other microorganisms associated with triatomines (Muscio et al., 1997; Marti et al., 2009). Consequently, it has been considered that people living in Chagas disease endemic areas may have entered in contact with $\operatorname{TrV}$ through virus particles present in triatomine feces (Muscio et al., 2000). This supposition has been confirmed by the positive serology for anti-TrV antibodies in mice (Querido et al., 2013), hens (Muscio et al., 2000), and rabbits (Muscio et al., 1997) used to feed triatomines infected with $\operatorname{TrV}$. Humans who live in endemic areas also showed positive TrV serology, among them $12.2 \%$ corresponded to healthy individuals (Querido et al., 2015), thus supporting the observation that $\operatorname{TrV}$ infection levels are higher/greater than T. cruzi infection levels in triatomines.

So far, the cases of $\operatorname{TrV}$ infection in vertebrates indicate that this virus is unable to replicate inside their cells (Muscio et al., 2000; Querido et al., 2013, 2015), and so may have no impact on human health. However, $\operatorname{TrV}$ may increase, indirectly, $T$. cruzi transmission to vertebrate hosts, strengthening triatomine vector competence for this trypanosomatid, although more studies are needed to confirm this hypothesis (Marti et al., 2017).

\section{FINAL CONSIDERATIONS}

In recent years, triatomines have undergone a major resurgence in the number of infestations, leading to re-emergence of $T$. cruzi vector transmission. Although the majority of Triatominae species occurs in the Americas, Linshcosteus spp. occur in India and T. rubrofasciata complex occurs in Africa, the Middle East, South-East Asia, and the Western Pacific countries (Dujardin et al., 2015). Although not all of Triatominae species are naturally infected with $T$. cruzi, there is the possibility of establishing vector transmission to areas where Chagas disease was previously non-endemic due to global population mobility. Furthermore, the resurgence and worldwide distribution of triatomines is concerning, considering they can enter in contact with other pathogens.

The possibility of these insects acting as vectors of other human pathogens aroused our curiosity. Triatomines are uncommon disease vectors since, except for salivarian trypanosomes as $T$. rangeli, pathogens seem unable to reach triatomine salivary glands in order to be transmitted by bite. Thus, the common route of transmission, as observed for $T$. cruzi, a stercorarian trypanosome, may be via contaminated feces released on skin wound or mucosa (Figure 3). We present reports of triatomine infected with vector pathogens ( $T$. rangeli and $\operatorname{TrV}$ ) already known to be transmitted to humans by triatomines, and of triatomines infected with human pathogens besides T. cruzi (the bacteria S. marcescens, Bartonella and $M$. leprae; and HIV and HBV) (Figure 3). Although no human viral disease can be attributed to Triatominae, $\operatorname{TrV}$ infection in triatomines may interfere with vector competence, augmenting the ability of triatomines to transmit Chagas disease. 
Many factors may influence triatomine vector competence for transmitting pathogens to humans. The different regions in the gut themselves can bear unfavorable conditions, for instance $\mathrm{pH}$, oxygen content, digestive enzymes, immune-related molecules, peristalsis, symbionts, and transient microorganisms (Douglas, 2015). Being competent does not mean to have the capacity to disseminate diseases, as vector competence is only one factor influencing vectorial capacity (Higgs and Beaty, 2004). Thus, further investigation and establishment of adapted models need to be developed in order to broaden the knowledge of triatominae ability to act as vector of other human infectious diseases.

\section{AUTHOR CONTRIBUTIONS}

$\mathrm{CdA}, \mathrm{CV}, \mathrm{YP}$, and $\mathrm{KB}$ were involved in the conception of and wrote the manuscript. PS, SS, GS, FM, IB and JdS wrote the manuscript. PS, YP, and KB prepared the figures and tables. All the authors read and approved the final manuscript.

\section{REFERENCES}

Åttman, E., Korhonen, P., Tammela, O., Vuento, R., Aittoniemi, J., Syrjänen, J., et al. (2018). A Serratia marcescens outbreak in a neonatal intensive care unit was successfully managed by rapid hospital hygiene interventions and screening. Acta Paediatr. 107, 425-429. doi: 10.1111/apa.14132

Agirre, J., Aloria, K., Arizmendi, J. M., Iloro, I., Elortza, F., Sánchez-Eugenia, R., et al. (2011). Capsid protein identification and analysis of mature Triatoma virus (TrV) virions and naturally occurring empty particles. Virology 409, 91-101. doi: 10.1016/j.virol.2010.09.034

Alevi, K. C., Moreira, F. F., Jurberg, J., and Azeredo-Oliveira, M. T. (2016). Description of the diploid chromosome set of Triatoma pintodiasi (Hemiptera, Triatominae). Genet. Mol. Res. 15:gmr.15026343. doi: 10.4238/gmr.15026343

Alevi, K. C., Rosa, J. A., and Azeredo-Oliveira, M. T. (2014). Cytotaxonomy of the Brasiliensis subcomplex and the Triatoma brasiliensis complex (Hemiptera: Reduviidae: Triatominae). Zootaxa 3838, 583-589. doi: 10.11646/zootaxa.3838.5.7

Almeida, C. E., Folly-Ramos, E., Peterson, A. T., Lima-Neiva, V., Gumiel, M., Duarte, R., et al. (2009). Could the bug Triatoma sherlocki be vectoring Chagas disease in small mining communities in Bahia, Brazil? Med. Vet. Entomol. 23, 410-417. doi: 10.1111/j.1365-2915.2009.00822.x

Azambuja, P., Feder, D., and Garcia, E. S. (2004). Isolation of Serratia marcescens in the midgut of Rhodnius prolixus: impact on the establishment of the parasite Trypanosoma cruzi in the vector. Exp. Parasitol. 107, 89-96. doi: 10.1016/j.exppara.2004.04.007

Banerjee, R., Banerjee, B. D., Chaudhury, S., and Hati, A. K. (1991). Transmission of viable Mycobacterium leprae by Aedes aegypti from lepromatous leprosy patients to the skin of mice through interrupted feeding. Lepr. Rev. 62, 21-26.

Benchimol, J. L., and Romero Sa, M. (2003). Adolpho Lutz and controversies over the transmission of leprosy by mosquitoes. Hist. Cienc Saude Manguinhos 10(Suppl. 1), 49-93. doi: 10.1590/S0104-59702003000400004

Billingsley, P. F., and Downe, A. E. (1986). The surface morphology of the midgut cells of Rhodnius prolixus Stål (Hemiptera: Reduviidae) during blood digestion. Acta Trop. 43, 355-366.

Caballero, Z. C., Costa-Martins, A. G., Ferreira, R. C., P. Alves, J. M., and Serrano, M. G., Camargo, E. P., et al. (2015). Phylogenetic and syntenic data support a single horizontal transference to a Trypanosoma ancestor of a prokaryotic proline racemase implicated in parasite evasion from host defences. Parasit. Vectors 8:222. doi: 10.1186/s13071-015-0829-y

Calzada, J. E., Pineda, V., Garisto, J. D., Samudio, F., Santamaria, A. M., and Saldaña, A. (2010). Human trypanosomiasis in the eastern region of the Panama Province: new endemic areas for Chagas disease. Am. J. Trop. Med. Hyg. 82, 580-582. doi: 10.4269/ajtmh.2010.09-0397

\section{FUNDING}

This study was supported by grants awarded to CdA and JdS from FAPDF (Distrito Federal Research Foundation, processes $193.001802 / 2017, \quad 193.001053 / 2015$ and $193.000822 / 2015)$ and to $\mathrm{CV}, \mathrm{YP}, \mathrm{KB}$ from CAPES (graduate student grant).

\section{ACKNOWLEDGEMENTS}

We would like to acknowledge Gabriel Soares Nunes for assistance with figure design.

\section{SUPPLEMENTARY MATERIAL}

The Supplementary Material for this article can be found online at: https://www.frontiersin.org/articles/10.3389/fcimb. 2018.00405/full\#supplementary-material

Candeias, J. A. N., Forattini, O. P., and Vieira, J. G. (1976). Hepatitis B antigen (HBsAg) in wild caught Triatominae in Brazil. Revista de Saúde Pública 10, 267-268. doi: 10.1590/S0034-89101976000300007

Carvalho, R. G. C., do Rosário Souza Carneiro, I. C., Pinheiro, M. S., da Costa Pinheiro, S., Roffe Azevedo, P. S., dos Santos, S. D., et al. (2010). Phenotypic and genotypic characterization of Serratia marcescens from a Neonatal Unit in Belém, Pará State, Brazil. Revista Pan Amazônica de Saúde 1, 101-106. doi: 10.5123/S2176-62232010000100015

Castro, G. V. S., Ribeiro, M. A. L., Ramos, L. J., Oliveira, J., Rosa, J. A. D., Camargo, L. M. A., et al. (2017). Rhodnius stali: new vector infected by Trypanosoma rangeli (Kinetoplastida, Trypanosomatidae). Rev. Soc. Brasil. Med. Trop. 50, 829-832. doi: 10.1590/0037-8682-0054-2017

Castro, M. C., Barrett, T. V., Santos, W. S., Abad-Franch, F., and Rafael, J. A. (2010). Attraction of Chagas disease vectors (Triatominae) to artificial light sources in the canopy of primary Amazon rainforest. Mem. Inst. Oswaldo Cruz 105, 1061-1064. doi: 10.1590/S0074-02762010000800019

Cavalier-Smith, T. (2016). Higher classification and phylogeny of Euglenozoa. Eur. J. Protistol. 56, 250-276. doi: 10.1016/j.ejop.2016.09.003

Cavassin, F. B., Kuehn, C. C., Kopp, R. L., Thomaz-Soccol, V., Da Rosa, J. A., Luz, E., et al. (2014). Genetic variability and geographical diversity of the main Chagas' disease vector Panstrongylus megistus (Hemiptera: Triatominae) in Brazil based on ribosomal DNA intergenic sequences. J. Med. Entomol. 51, 616-628. doi: 10.1603/ME13073

Coura, J. R., Fernandes, O., Arboleda, M., Barrett, T. V., Carrara, N., Degrave, W., et al. (1996). Human infection by Trypanosoma rangeli in the Brazilian Amazon. Trans. R. Soc. Trop. Med. Hygiene 90, 278-279.

Cuba Cuba, A. (1998). Review of biological and diagnostic aspects of Trypanosoma (Herpetosoma) rangeli. Revista Soc. Brasil. Med. Tropical 31, 207-220.

Cullen, M. M., Trail, A., Robinson, M., Keaney, M., and Chadwick, P. R. (2005). Serratia marcescens outbreak in a neonatal intensive care unit prompting review of decontamination of laryngoscopes. J. Hosp. Infect. 59, 68-70. doi: 10.1016/j.jhin.2004.08.003

Curtis-Robles, R., Hamer, S. A., Lane, S., Levy, M. Z., and Hamer, G. L. (2018). Bionomics and spatial distribution of triatomine vectors of. Am. J. Trop. Med. Hyg. 98, 113-121. doi: 10.4269/ajtmh.17-0526

Czibener, C., La Torre, J. L., Muscio, O. A., Ugalde, R. A., and Scodeller, E. A. (2000). Nucleotide sequence analysis of Triatoma virus shows that it is a member of a novel group of insect RNA viruses. J. Gen. Virol. 81(Pt 4), 1149-1154. doi: 10.1099/0022-1317-81-4-1149

da Rosa, J. A., Justino H. H. G., Nascimento J. D., Mendonça V. J., Rocha, C. S., de Carvalho D. B., et al. (2017). A new species of Rhodnius from Brazil (Hemiptera, Reduviidae, Triatominae). Zookeys 675, 1-25. doi: 10.3897/zookeys.675. 12024 
Da Silva, F. M., Marcili, A., Lima, L., Cavazzana, M. Jr., Ortiz, P. A., Campaner, M., et al. (2009). Trypanosoma rangeli isolates of bats from Central Brazil: genotyping and phylogenetic analysis enable description of a new lineage using spliced-leader gene sequences. Acta Trop. 109, 199-207. doi: 10.1016/j.actatropica.2008.11.005

Da Silva, F. M., Noyes, H., Campaner, M., Junqueira, A. C., Coura, J. R., Añez, N., et al. (2004). Phylogeny, taxonomy and grouping of Trypanosoma rangeli isolates from man, triatomines and sylvatic mammals from widespread geographical origin based on SSU and ITS ribosomal sequences. Parasitology 129, 549-561. doi: 10.1017/S0031182004005931

D’Alessandro, A. (1976). "Biology of Trypanosoma (Herpetosoma) rangeli Tejera, (1920)," in Biology of the Kinetoplastida, Vol. 1, eds W. Lumsden and D. Evans (London: Academic Press), 327-403.

Dario, M. A., Lisboa, C. V., Costa, L. M., Moratelli, R., Nascimento, M. P., Costa, L. P., et al. (2017). High Trypanosoma spp. diversity is maintained by bats and triatomines in Espírito Santo state, Brazil. PLoS ONE 12:e188412. doi: 10.1371/journal.pone.0188412

Dario, M. A., Rodrigues, M. S., Barros, J. H., Xavier, S. C., D’Andrea, P. S., Roque, A. L., et al. (2016). Ecological scenario and Trypanosoma cruzi DTU characterization of a fatal acute Chagas disease case transmitted orally (Espírito Santo state, Brazil). Parasit. Vectors 9:477. doi: 10.1186/s13071-016-1754-4

de Moraes, M. H., Guarneri, A. A., Girardi, F. P., Rodrigues, J. B., Eger, I., Tyler, K. M., et al. (2008). Different serological cross-reactivity of Trypanosoma rangeli forms in Trypanosoma cruzi-infected patients sera. Parasit. Vectors 1:20. doi: 10.1186/1756-3305-1-20

de Scorza, C., Urdaneta-Morales, S., and Tejero, F. (1986). Trypanosoma (Herpetosoma) rangeli Tejera, 1920: Preliminary report on histopathology in experimentally infected mice. Revista do Instituto de Medicina Tropical de São Paulo 28, 371-378.

de Souza-Araujo, H.C. (1942). Poderá o carrapato transmitir a lepra? Memórias do Instituto Oswaldo Cruz 37:95.

Desikan, K. V., and Sreevatsa. (1995). Extended studies on the viability of Mycobacterium leprae outside the human body. Lepr. Rev. 66, 287-295.

Desquesnes, M., Bosseno, M. F., and Brenière, S. F. (2007). Detection of Chagas infections using Trypanosoma evansi crude antigen demonstrates high cross-reactions with Trypanosoma cruzi. Infect. Genet. Evol. 7, 457-462. doi: 10.1016/j.meegid.2007.01.007.

Dias, J. C. P., and Schofield, C. J. (1998). Controle da transmissão transfusional da doença de Chagas na Iniciativa do Cone Sul. Revista da Sociedade Brasileira de Medicina Tropical 31, 373-383.

Domier, L. L., McCoppin, N. K., and D’Arcy, C. J. (2000). Sequence requirements for translation initiation of Rhopalosiphum padi virus ORF2. Virology 268, 264-271. doi: 10.1006/viro.2000.0189

Douglas, A. E. (2015). Multiorganismal insects: diversity and function of resident microorganisms. Annu. Rev. Entomol. 60, 17-34. doi: 10.1146/annurev-ento-010814-020822

Dujardin, J. P., Lam, T. X., Khoa, P. T., and Schofield, C. J. (2015). The rising importance of Triatoma rubrofasciata. Mem. Inst. Oswaldo Cruz 110, 319-323. doi: 10.1590/0074-02760140446

Edwards, M. S., Kelly, K. S., and Susan, P. M. (2017). Addressing the challenges of chagas disease: an emerging health concern in the United States. Infect. Dis. Clin. Pract. 25, 118-125. doi: 10.1097/IPC.0000000000000512

Espinosa-Álvarez, O., Ortiz, P. A., Lima, L., Costa-Martins, A. G., Serrano, M. G., Herder, S., et al. (2018). Trypanosoma rangeli is phylogenetically closer to Old World trypanosomes than to Trypanosoma cruzi. Int. J. Parasitol. 48, 569-584. doi: 10.1016/j.ijpara.2017.12.008

Fellet, M. R., Lorenzo, M. G., Elliot, S. L., Carrasco, D., and Guarneri, A. A. (2014). Effects of infection by Trypanosoma cruzi and Trypanosoma rangeli on the reproductive performance of the vector Rhodnius prolixus. PLoS ONE 9:e105255. doi: 10.1371/journal.pone.0105255

Ferreira Lde, L., Pereira, M. H., and Guarneri, A. A. (2015). Revisiting Trypanosoma rangeli transmission involving susceptible and non-susceptible hosts. PLoS ONE 10:e0140575. doi: 10.1371/journal.pone.0140575

Ferreira, L. L., Lorenzo, M. G., Elliot, S. L., and Guarneri, A. A. (2010). A standardizable protocol for infection of Rhodnius prolixus with Trypanosoma rangeli, which mimics natural infections and reveals physiological effects of infection upon the insect. J. Invertebr. Pathol. 105, 91-97. doi: $10.1016 /$ j.jip.2010.05.013
Figueiredo, A. R. (1995). Isolamento da Microbiota Bacteriana de Triatomíneos e Persistência do Enterobacter cloacae em Rhodnius prolixus Stal (1859). MSc. Thesis, Instituto Oswaldo Cruz.

Figueiredo, R. C., Rosa, D. S., and Soares, M. J. (2000). Differentiation of Trypanosoma cruzi epimastigotes: metacyclogenesis and adhesion to substrate are triggered by nutritional stress. J. Parasitol. 86, 1213-1218. doi: 10.1645/ 0022-3395(2000)086[1213:DOTCEM]2.0.CO;2

Fleisch, F., Zimmermann-Baer, U., Zbinden, R., Bischoff, G., Arlettaz, R., Waldvogel, K., et al. (2002). Three consecutive outbreaks of Serratia marcescens in a neonatal intensive care unit. Clin. Infect. Dis. 34, 767-773. doi: $10.1086 / 339046$

Frankel, A. D., and Young, J. A. (1998). HIV-1: fifteen proteins and an RNA. Annu. Rev. Biochem. 67, 1-25. doi: 10.1146/annurev.biochem.67.1.1

Garcia, E. S., Genta, F. A., de Azambuja, P., and Schaub, G. A. (2010). Interactions between intestinal compounds of triatomines and Trypanosoma cruzi. Trends Parasitol.. 26, 499-505. doi: 10.1016/j.pt.2010.07.003

Garcia, E. S., Ratcliffe, N. A., Whitten, M. M., Gonzalez, M. S., and Azambuja, P. (2007). Exploring the role of insect host factors in the dynamics of Trypanosoma cruzi-Rhodnius prolixus interactions. J. Insect Physiol. 53, 11-21. doi: 10.1016/j.jinsphys.2006.10.006

Gil-Jaramillo, N., Motta, F. N., Favali, C. B., Bastos, I. M., and Santana, J. M. (2016). Dendritic cells: a double-edged sword in immune responses during chagas disease. Front. Microbiol. 7:1076. doi: 10.3389/fmicb.2016.01076

González-Juarbe, N., Mares, C. A., Hinojosa, C. A., Medina, J. L., Cantwell, A., Dube, P. H., et al. (2015). Requirement for Serratia marcescens cytolysin in a murine model of hemorrhagic pneumonia. Infect. Immun. 83, 614-624. doi: 10.1128/IAI.01822-14

Granato, Hernandes, C. F., de Mendonça, Silva Pinto, P. L., Neto, V. A., Veronesi, R., and Tolezano, E. (1987). Papel de triatomíneos na transmissäo de infecçäo pelo vírus da hepatite tipo B, em diferentes normas clínicas da doença. Rev. Hosp. Clin. Fac. Med. Sao Paulo 42, 173-175.

Gransden, W. R., Webster, M., French, G. L., and Phillips, I. (1986). An outbreak of Serratia marcescens transmitted by contaminated breast pumps in a special care baby unit. J. Hosp. Infect. 7, 149-154.

Grimont, P. A. D., and Grimont, F. (1978). The genus Serratia. Ann. Rev. Microbiol. 32, 221-248.

Grimont, P. A. D., Grimont, F., and Lysenko, O. (1979). Species and biotype identification of Serratia strains associated with insects. Curr. Microbiol. 2, 139-142.

Grisard, E. C., Steindel, M., Guarneri, A. A., Eger-Mangrich, I., Campbell, D. A., and Romanha, A. J. (1999a). Characterization of Trypanosoma rangeli strains isolated in Central and South America: an overview. Mem. Inst. Oswaldo Cruz 94, 203-209.

Grisard, E. C., Steindel, M., Guarneri, A. A., Eger-Mangrich, I., Campbell, D. A., and Romanha, A. J. (1999b). Characterization of Trypanosoma rangeli strains isolated in Central and South America: an overview. Memórias do Instituto Oswaldo Cruz 94, 203-209.

Guarneri, A. A., Pereira, M. H., and Diotaiuti, L. (2000). Influence of the blood meal source on the development of Triatoma infestans, Triatoma brasiliensis, Triatoma sordida, and Triatoma pseudomaculata (Heteroptera, Reduviidae). J. Med. Entomol. 37, 373-379. doi: 10.1093/jmedent/37.3.373

Guhl, F., Hudson, L., Marinkelle, C. J., Jaramillo, C. A., and Bridge, D. (1987). Clinical Trypanosoma rangeli infection as a complication of Chagas 'disease. Parasitology 94, 475-484.

Guhl, F., and Marinkelle, C. J. (1982). Antibodies against Trypanosoma cruzi in mice infected with T. rangeli. Ann. Trop. Med. Parasitol. 76:361.

Guhl, F., and Vallejo, G. A. (2003). Trypanosoma (Herpetosoma) rangeli Tejera, 1920: an updated review. Mem. Inst. Oswaldo Cruz 98, 435-442. doi: 10.1590/S0074-02762003000400001

Higgs, S., and Beaty, B. J. (2004). "Natural cycles of vector-borne pathogens," in The Biology of Disease Vectors, ed W. H. Marquardt (Burlington, NJ: Elsevier Academic Press), 167-186.

Hoare, C. A. (1972). The trypanosomes of mammals. A Zoological Monograph. Oxford; Edinburgh: Blackwell Scientific Publication.

Jang, T. N., Fung, C. P., Yang, T. L., Shen, S. H., Huang, C. S., and Lee, S. H. (2001). Use of pulsed-field gel electrophoresis to investigate an outbreak of Serratia marcescens infection in a neonatal intensive care unit. J. Hosp. Infect. 48, 13-19. doi: 10.1053/jhin.2001.0947 
Johnson, K. N., and Christian, P. D. (1998). The novel genome organization of the insect picorna-like virus Drosophila $\mathrm{C}$ virus suggests this virus belongs to a previously undescribed virus family. J. Gen. Virol. 79 (Pt 1), 191-203. doi: 10.1099/0022-1317-79-1-191

Jones, B. L., Gorman, L. J., Simpson, J., Curran, E. T., McNamee, S., Lucas, C., et al. (2000). An outbreak of Serratia marcescens in two neonatal intensive care units. J. Hosp. Infect. 46, 314-319. doi: 10.1053/jhin.2000.0837

Jurberg, J., Rodrigues, J. M. S., Moreira, F. F. F., Dale, C., Cordeiro, I. R. S., and Valdir, D., Jr. (2014). Atlas Iconográfico dos triatomíneos do Brasil (Vetores da doença de Chagas). Laboratorio Nacional e Internacional de Referencia em Taxonomia de Triatomineos, Instituto Oswaldo Cruz.

Kirchheimer, W. F. (1976). The role of arthropods in the transmission of leprosy. Int. J. Lepr. Other Mycobact. Dis. 44, 104-107.

Klotz, J. H., Dorn, P. L., Logan, J. L., Stevens, L., Pinnas, J. L., Schmidt, J. O., et al. (2010). "Kissing bugs": potential disease vectors and cause of anaphylaxis. Clin. Infect. Dis. 50, 1629-1634. doi: 10.1086/652769

Kollien, A. H., and Schaub, G. A. (2000). The development of Trypanosoma cruzi in triatominae. Parasitol. Today 16, 381-387. doi: 10.1016/S0169-4758(00)01724-5

Lainson, R., Shaw, J. J., Fraiha, H., Miles, M. A., and Draper, C. C. (1979). Chagas's Disease in the Amazon Basin: 1. Trypanosoma cruzi infections in silvatic mammals, triatomine bugs and man in the State of Pará, North Brazil. Trans. R. Soc. Trop. Med. Hyg. 73, 193-204.

Laroche, M., Berenger, J. M., Mediannikov, O., Raoult, D., and Parola, P. (2017). Detection of a potential new Bartonella Species Candidatus Bartonella rondoniensis in human biting kissing bugs (Reduviidae; Triatominae). PLoS Negl. Trop. Dis. 11:e0005297. doi: 10.1371/journal.pntd.0005297

Lazzari, C. R., Pereira, M. H., and Lorenzo, M. G. (2013). Behavioural biology of Chagas disease vectors. Mem. Inst. Oswaldo Cruz 108(Suppl. 1), 34-47. doi: 10.1590/0074-0276130409

Lent, H., and Wygodzinsky, P. (1979). Revision of the Triatominae (Hemiptera, Reduviidae) and their significanse as vectors of Chagas disease. Bull. Am. Mus. Nat. Hist. 163, 125-520.

Liang, T. J. (2009). Hepatitis B: the virus and disease. Hepatology 49(5 Suppl), S13-21. doi: 10.1002/hep.22881

Maguiña, C., and Gotuzzo, E. (2000). Bartonellosis. New and old. Infect. Dis. Clin. North Am. 14, 1-22. doi: 10.1016/S0891-5520(05)70215-4

Mahlen, S. D. (2011). Serratia infections: from military experiments to current practice. Clin. Microbiol. Rev. 24, 755-791. doi: 10.1128/CMR.00017-11

Maia Da Silva, F., Junqueira, A. C., Campaner, M., Rodrigues, A. C., Crisante, G., Ramirez, L. E., et al. (2007). Comparative phylogeography of Trypanosoma rangeli and Rhodnius (Hemiptera: Reduviidae) supports a long coexistence of parasite lineages and their sympatric vectors. Mol. Ecol. 16, 3361-3373. doi: 10.1111/j.1365-294X.2007.03371.x

Maia da Silva, F., Rodrigues, A. C., Campaner, M., Takata, C. S., Brigido, M. C., Junqueira, A. C., et al. (2004). Randomly amplified polymorphic DNA analysis of Trypanosoma rangeli and allied species from human, monkeys and other sylvatic mammals of the Brazilian Amazon disclosed a new group and a species-specific marker. Parasitology 128(Pt 3), 283-294. doi: $10.1017 /$ S0031182003004554

Maillard, R., Petit, E., Chomel, B., Lacroux, C., Schelcher, F., Vayssier-Taussat, M., et al. (2007). Endocarditis in cattle caused by Bartonella bovis. Emerg. Infect. Dis. 13, 1383-1385. doi: 10.3201/eid1309.070236

Maragakis, L. L., Winkler, A., Tucker, M. G., Cosgrove, S. E., Ross, T., Lawson, E., et al. (2008). Outbreak of multidrug-resistant Serratia marcescens infection in a neonatal intensive care unit. Infect. Control Hosp. Epidemiol. 29, 418-423. doi: $10.1086 / 587969$

Marliére, N. P., Latorre-Estivalis, J. M., Lorenzo, M. G., Carrasco, D., Alves-Silva, J., Rodrigues, Jde, O., et al. (2015). Trypanosomes modify the behavior of their insect hosts: effects on locomotion and on the expression of a related Gene. PLoS Negl. Trop. Dis. 9:e0003973. doi: 10.1371/journal.pntd.0003973

Marti, G. A., Echeverria, M. G., Susevich, M. L., Becnel, J. J., Pelizza, S. A., and García, J. J. (2009). Prevalence and distribution of parasites and pathogens of triatominae from Argentina, with emphasis on Triatoma infestans and Triatoma virus TrV. J. Invertebr. Pathol. 102, 233-237. doi: 10.1016/j.jip.2009.06.010

Marti, G. A., Ragone, P., Balsalobre, A., Ceccarelli, S., Susevich, M. L., Diosque, P., et al. (2017). Can Triatoma virus inhibit infection of Trypanosoma cruzi
(Chagas, 1909) in Triatoma infestans (Klug)? A cross infection and coinfection study. J. Invertebr. Pathol. 150, 101-105. doi: 10.1016/j.jip.2017. 09.014

Matsuoka, M., Izumi, S., Budiawan, T., Nakata, N., and Saeki, K. (1999). Mycobacterium leprae DNA in daily using water as a possible source of leprosy infection. Indian J. Lepr. 71, 61-67.

McFadzean, J. A., and Macdonald, W. W. (1961). An investigation of the possible role of mosquitoes and bed bugs in the transmission of leprosy. Trans. R. Soc. Trop. Med. Hyg. 55, 232-234.

Minnick, M. F., Anderson, B. E., Lima, A., Battisti, J. M., Lawyer, P. G., and Birtles, R. J. (2014). Oroya fever and verruga peruana: bartonelloses unique to South America. PLoS Negl. Trop. Dis. 8:e2919. doi: 10.1371/journal.pntd.0002919

Montagnani, C., Cocchi, P., Lega, L., Campana, S., Biermann, K. P., Braggion, C., et al. (2015). Serratia marcescens outbreak in a neonatal intensive care unit: crucial role of implementing hand hygiene among external consultants. BMC Infect. Dis. 15:11. doi: 10.1186/s12879-014-0734-6

Montgomery, S. P., Starr, M. C., Cantey, P. T., Edwards, M. S., and Meymandi, S. K. (2014). Neglected parasitic infections in the United States: Chagas disease. Am. J. Trop. Med. Hyg. 90, 814-818. doi: 10.4269/ajtmh.13-0726

Mühldorfer, K. (2013). Bats and bacterial pathogens: a review. Zoonoses Public Health 60, 93-103. doi: 10.1111/j.1863-2378.2012.01536.x

Mullins, K. E., Hang, J., Jiang, J., Leguia, M., Kasper, M. R., Ventosilla, P., et al. (2015). Description of Bartonella ancashensis sp. nov., isolated from the blood of two patients with verruga peruana. Int. J. Syst. Evol. Microbiol. 65, 3339-3343. doi: 10.1099/ijsem.0.000416

Muscio, O., Bonder, M. A., La Torre, J. L., and Scodeller, E. A. (2000). Horizontal transmission of triatoma virus through the fecal-oral route in Triatoma infestans (Hemiptera: Triatomidae). J. Med. Entomol. 37, 271-275. doi: 10.1603/0022-2585-37.2.271

Muscio, O. A., La Torre, J., Bonder, M. A., and Scodeller, E. A. (1997). Triatoma virus pathogenicity in laboratory colonies of Triatoma infestans (Hemiptera:Reduviidae). J. Med. Entomol. 34, 253-256.

Muscio, O. A., La Torre, J. L., and Scodeller, E. A. (1988). Characterization of Triatoma virus, a picorna-like virus isolated from the triatomine bug Triatoma infestans. J. Gen. Virol. 69(Pt 11), 2929-2934. doi: 10.1099/0022-1317-69-11-2929

Muscio, O. A., LaTorre, J. L., and Scodeller, E. A. (1987). Small nonoccluded viruses from triatomine bug Triatoma infestans (Hemiptera: Reduviidae). J. Invertebr. Pathol. 49, 218-220.

Neumann Ada, S., Dias Fde, A., Ferreira Jda, S., Fontes, A. N., Rosa, P. S., Macedo, R. E., et al. (2016). Experimental infection of Rhodnius prolixus (Hemiptera, Triatominae) with Mycobacterium leprae indicates potential for leprosy transmission. PLoS ONE 11:e0156037. doi: 10.1371/journal.pone.01 56037

Nuzzo, S., Amato Neto, V., Braz, L., Silva, M., Oliveira, M., Castilho, M., et al. (1998). Evaluation of presence of protein 24 from HIV in feces of Triatoma infestans fed blood from HIV positive patients. Revista de Saúde Pública 32, 464-466. doi: 10.1590/S0034-891019980005 00009

Ocaña-Mayorga, S., Aguirre-Villacis, F., Pinto, C. M., Vallejo, G. A., and Grijalva, M. J. (2015). Prevalence, genetic characterization, and $18 \mathrm{~S}$ small subunit ribosomal RNA diversity of Trypanosoma rangeli in triatomine and mammal hosts in endemic areas for Chagas disease in Ecuador. Vector Borne Zoonot. Dis. 15, 732-742. doi: 10.1089/vbz.2015.1794

Ortiz, P. A., Maia da Silva, F., Cortez, A. P., Lima, L., Campaner, M., Pral, E. M., et al. (2009). Genes of cathepsin L-like proteases in Trypanosoma rangeli isolates: markers for diagnosis, genotyping and phylogenetic relationships. Acta Trop. 112, 249-259. doi: 10.1016/j.actatropica.2009. 07.036

Osorio, Y., Travi, B. L., Palma, G. I., and Saravia, N. G. (1995). Infectivity of Trypanosoma rangeli in a promonocytic mammalian cell line. J. Parasitol. 81, 687-693.

Otálora-Luna, F., A., Pérez-Sánchez, J., Sandoval, C., and Aldana, E. (2015). Evolution of hematophagous habit in Triatominae (Heteroptera: Reduviidae). Rev. Chil. de Hist. Nat. 88:4. doi: 10.1186/s40693-0140032-0

Paige, C. F., Scholl, D. T., and Truman, R. W. (2002). Prevalence and incidence density of Mycobacterium leprae and Trypanosoma cruzi infections within 
a population of wild nine-banded armadillos. Am. J. Trop. Med. Hyg. 67, 528-532. doi: 10.4269/ajtmh.2002.67.528

Paim, R. M. M., Pereira, M. H., Araújo, R. N., Gontijo, N. F., and Guarneri, A. A. (2013). The interaction between Trypanosoma rangeli and the nitrophorins in the salivary glands of the triatomine Rhodnius prolixus (Hemiptera; Reduviidae). Insect Biochem. Mol. Biol. 43, 229-236. doi: 10.1016/j.ibmb.2012.12.011

Peterson, J. K., and Graham, A. L. (2016). What is the 'true' effect of Trypanosoma rangeli on its triatomine bug vector? J. Vector Ecol. 41, 27-33. doi: $10.1111 /$ jvec. 12190

Peterson, J. K., Graham, A. L., Elliott, R. J., Dobson, A. P., and Triana Chávez, O. (2016). Trypanosoma cruzi-Trypanosoma rangeli coinfection ameliorates negative effects of single trypanosome infections in experimentally infected Rhodnius prolixus. Parasitology 143, 1157-1167. doi: $10.1017 /$ S0031182016000615

Pinto, C. M., Kalko, E. K., Cottontail, I., Wellinghausen, N., and Cottontail, V. M. (2012). TcBat a bat-exclusive lineage of Trypanosoma cruzi in the Panama Canal Zone, with comments on its classification and the use of the $18 \mathrm{~S}$ rRNA gene for lineage identification. Infect. Genet. Evol. 12, 1328-1332. doi: 10.1016/j.meegid.2012.04.013

Pinto, C. M., Ocaña-Mayorga, S., Tapia, E. E., Lobos, S. E., Zurita, A. P., AguirreVillacís, F., et al. (2015). Bats, Trypanosomes, and Triatomines in Ecuador: new insights into the diversity, transmission, and origins of Trypanosoma cruzi and Chagas disease. PLoS ONE 10:e0139999. doi: 10.1371/journal.pone.0139999

Pons, M. J., Gomes, C., Del Valle-Mendoza, and Ruiz, J. (2016). Carrion's disease: more than a sand fly-vectored illness. PLoS Pathog. 12:e1005863. doi: 10.1371/journal.ppat.1005863

Querido, J. F., Agirre, J., Marti, G. A., Guérin, D. M., and Silva, M. S. (2013). Inoculation of Triatoma virus (Dicistroviridae: Cripavirus) elicits a non-infective immune response in mice. Parasit. Vectors 6:66. doi: 10.1186/1756-3305-6-66

Querido, J. F., Echeverría, M. G., Marti, G. A., Costa, R. M., Susevich, M. L., Rabinovich, J. E., et al. (2015). Seroprevalence of Triatoma virus (Dicistroviridae: Cripaviridae) antibodies in Chagas disease patients. Parasit. Vectors 8:29. doi: 10.1186/s13071-015-0632-9

Rassi, A. Jr., Rassi, A., and Marin-Neto, J. A. (2010). Chagas disease. Lancet 375, 1388-1402. doi: 10.1016/S0140-6736(10)60061-X

Regier, Y., O., Rourke, F., and Kempf, V. A. (2016). Bartonella spp. - a chance to establish One Health concepts in veterinary and human medicine. Parasit. Vectors 9:261. doi: 10.1186/s13071-016-1546-x

Rodríguez-Ruano, S. M., Škochová, V., Rego, R. O. M., Schmidt, J. O., Roachell, W., Hypša, V., et al. (2018). Microbiomes of North American Triatominae: the grounds for Chagas Disease epidemiology. Front. Microbiol. 9:1167. doi: $10.3389 /$ fmicb.2018.01167

Rozas-Dennis, G. S., and Cazzaniga, N. J. (2000). Effects of Triatoma virus (TrV) on the fecundity and moulting of Triatoma infestans (Hemiptera: Reduviidae). Ann. Trop. Med. Parasitol. 94, 633-641. doi: 10.1080/00034983.2000.118 13586

Sanchez Clemente, N., Ugarte-Gil, C. A., Solórzano, N., Maguiña, C., Pachas, P., Blazes, D., et al. (2012). Bartonella bacilliformis: a systematic review of the literature to guide the research agenda for elimination. PLoS Negl. Trop. Dis. 6:e1819. doi: 10.1371/journal.pntd.0001819

Sartor, C., Jacomo, V., Duvivier, C., Tissot-Dupont, H., Sambuc, R., and Drancourt, M. (2000). Nosocomial Serratia marcescens infections associated with extrinsic contamination of a liquid nonmedicated soap. Infect. Control. Hosp. Epidemiol. 21, 196-199. doi: 10.1086/501743

Sasaki, J., Nakashima, N., Saito, H., and Noda, H. (1998). An insect picorna-like virus, Plautia stali intestine virus, has genes of capsid proteins in the 3' part of the genome. Virology 244, 50-58. doi: 10.1006/viro.1998.9094

Schaub, G. A. (1989). Does Trypanosoma cruzi stress its vectors? Parasitology Today $5,185-188$

Schaub, G. A., Meiser, C. K., and Balczun, C. (2011). "Interactions of Trypanosoma cruzi and triatomines," in Progress in Parasitology, ed H. Mehlhorn (Berlin; Heidelberg: Springer) 155-178.

Schofield, C. J. (1988) "The biosystematics of Triatominae," in Biosystematics of Haematophagous Insects, Vol. 37, ed M. W. Service (Oxford University Press), 284-312.
Schuster, J. P., and Schaub, G. A. (2000). Trypanosoma cruzi: skin-penetration kinetics of vector-derived metacyclic trypomastigotes. Int. J. Parasitol. 30, 1475-1479. doi: 10.1016/S0020-7519(00)00119-3

Scollard, D. M., Adams, L. B., Gillis, T. P., Krahenbuhl, J. L., Truman, R. W., and Williams, D. L. (2006). The continuing challenges of leprosy. Clin. Microbiol. Rev. 19, 338-381. doi: 10.1128/CMR.19.2.338-381.2006

Sincero, T. C., Stoco, P. H., Steindel, M., Vallejo, G. A., and Grisard, E. C. (2015). Trypanosoma rangeli displays a clonal population structure, revealing a subdivision of $\mathrm{KP} 1(-)$ strains and the ancestry of the Amazonian group. Int. J. Parasitol. 45, 225-235. doi: 10.1016/j.ijpara.2014.11.004

Smith, J. H., Folse, D. S., Long, E. G., Christie, J. D., Crouse, D. T., Tewes, M. E., et al. (1983). Leprosy in wild armadillos (Dasypus novemcinctus) of the Texas Gulf Coast: epidemiology and mycobacteriology. J. Reticuloendothelial Soc. 34, $75-88$.

Souza, E. D., Von Atzingen, N. C., Furtado, M. B., de Oliveira, J., Nascimento, J. D., Vendrami, D. P., et al. (2016). Description of Rhodnius marabaensis sp. n. (Hemiptera, Reduviidae, Triatominae) from Pará State, Brazil. ZooKeys 621, 45-62. doi: 10.3897/zookeys.621.9662

Tarleton, R. L. (2007). Immune system recognition of Trypanosoma cruzi. Curr Opin Immunol 19, 430-434. doi: 10.1016/j.coi.2007.06.003

Teixeira, A. R., Hecht, M. M., Guimaro, M. C., Sousa, A. O., and Nitz, N. (2011). Pathogenesis of chagas' disease: parasite persistence and autoimmunity. Clin. Microbiol. Rev. 24, 592-630. doi: 10.1128/CMR.00063-10

Truman, R. W., Singh, P., Sharma, R., Busso, P., Rougemont, J., Paniz-Mondolfi, A., et al. (2011). Probable zoonotic leprosy in the southern United States. N. Engl. J. Med. 364, 1626-1633. doi: 10.1056/NEJMoa1010536

Tsai, Y. L., Chang, C. C., Chuang, S. T., and Chomel, B. B. (2011). Bartonella species and their ectoparasites: selective host adaptation or strain selection between the vector and the mammalian host? Comp. Immunol. Microbiol. Infect. Dis. 34, 299-314. doi: 10.1016/j.cimid.2011.04.005

Turankar, R. P., Lavania, M., Singh, M., Sengupta, U., Siva Sai, K., and Jadhav, R. S. (2016). Presence of viable Mycobacterium leprae in environmental specimens around houses of leprosy patients. Indian J. Med. Microbiol. 34, 315-321. doi: 10.4103/0255-0857.188322

Turankar, R. P., Lavania, M., Singh, M., Siva Sai, K. S., and Jadhav, R. S. (2012). Dynamics of Mycobacterium leprae transmission in environmental context: deciphering the role of environment as a potential reservoir. Infect. Genet. Evol. 12, 121-126. doi: 10.1016/j.meegid.2011.10.023

Tyler, K. M., and Engman, D. M. (2001). The life cycle of Trypanosoma cruzi revisited. Int. J. Parasitol. 31, 472-481. doi: 10.1016/S0020-7519(01)00153-9

Uduman, S. A., Farrukh, A. S., Nath, K. N., Zuhair, M. Y., Ifrah, A., Khawla, A. D., et al. (2002). An outbreak of Serratia marcescens infection in a special-care baby unit of a community hospital in United Arab Emirates: the importance of the air conditioner duct as a nosocomial reservoir. J. Hosp. Infect. 52, 175-180. doi: 10.1053/jhin.2002.1308

Urdaneta-Morales, S., and Tejero, F. (1986). Trypanosoma (Herpetosoma) rangeli Tejera, 1920: intracellular amastigote stages of reproduction in white mice. Revis. Inst. Med. Trop. São Paulo 28, 166-169.

Vallejo, G. A., Guhl, F., and Schaub, G. A. (2009). Triatominae-Trypanosoma cruzi/T. rangeli: vector-parasite interactions. Acta Trop. 110, 137-147. doi: 10.1016/j.actatropica.2008.10.001

Vallejo, G. A., Suárez, J., Olaya, J. L., Gutierrez, S. A., and Carranza, J. C. (2015). Trypanosoma rangeli: un protozoo infectivo y no patógeno para el humano que contribuye al entendimiento de la transmisión vectorial y la infección por Trypanosoma cruzi, agente causal de la enfermedad de Chagas. Revista de la Academia Colombiana de Ciencias Exactas, Físicas y Naturales 39, 111-122. doi: 10.18257/raccefyn. 143

Villari, P., Crispino, M., Salvadori, A., and Scarcella, A. (2001). Molecular epidemiology of an outbreak of Serratia marcescens in a neonatal intensive care unit. Infect. Control Hosp. Epidemiol. 22, 630-634. doi: 10.1086/501834

Walsh, G. P., Storrs, E. E., Burchfield, H. P., Cotrell, E. H., Vidrine, M. F., and Binford, C. H. (1975). Leprosy-like disease occurring naturally in armadillos. J. Reticuloendothelial Soc. 18, 347-351.

Walter, J., Fletcher, E., Moussaoui, R., Gandhi, K., and Weirauch, C. (2012). Do bites of kissing bugs cause unexplained allergies? Results from a survey in triatomine-exposed and unexposed areas in southern California. PLOS ONE 7:e44016. doi: 10.1371/journal.pone.0044016 
WHO (2015). Leprosy Elimination. Available online at: http://www.who.int/lep/ disease/en/ (Accessed March 14, 2018).

WHO (2016). Global Leprosy Strategy 2016-2020: Accelerating Towards a LeprosyFree World.

WHO (2017). Vector-Borne Diseases. Available online at: http://www.who.int/ en/news-room/fact-sheets/detail/vector-borne-diseases (Accessed October 14, 2018).

WHO (2018a). Chagas Disease (American trypanosomiasis) - Epidemiology. Available online at: http://www.who.int/chagas/epidemiology/en/ (Accessed October 10, 2018).

WHO (2018b). Chagas disease (American trypanosomiasis). Available online at: http://www.who.int/mediacentre/factsheets/fs340/en/ (Accessed July 29, 2018).

WHO (2018c). HIV/AIDS. Available online at: http://www.who.int/news-room/ fact-sheets/detail/hiv-aids (Accessed September 22, 2018).

WHO (2018d). Hepatitis, B. Available online at: http://www.who.int/news-room/ fact-sheets/detail/hepatitis-b (Accessed October 04, 2018).

WHO/TDR (2012). Research Priorities for Chagas Disease, Human African Trypanosomiasis and Leishmaniasis. Technical Report of the TDR Disease
Reference Group on Chagas Disease, Human African Trypanosomiasis and Leishmaniasis. World Health Organization.

Wilson, J. E., Powell, M. J., Hoover, S. E., and Sarnow, P. (2000). Naturally occurring dicistronic cricket paralysis virus RNA is regulated by two internal ribosome entry sites. Mol. Cell Biol. 20, 4990-4999.

Conflict of Interest Statement: The authors declare that the research was conducted in the absence of any commercial or financial relationships that could be construed as a potential conflict of interest.

Copyright (c) 2018 Vieira, Praça, Bentes, Santiago, Silva, Silva, Motta, Bastos, de Santana and de Araújo. This is an open-access article distributed under the terms of the Creative Commons Attribution License (CC BY). The use, distribution or reproduction in other forums is permitted, provided the original author $(s)$ and the copyright owner(s) are credited and that the original publication in this journal is cited, in accordance with accepted academic practice. No use, distribution or reproduction is permitted which does not comply with these terms. 